\title{
地下水中の好・嫌気性菌によるSUS304Lおよび SUS316L 鋼溶接部の微生物誘起腐食（第一報） 一研究室における再現実験と腐食挙動一
}

\author{
菊地 靖志 $*$. 小澤 正義*2 $\cdot$ 塔本 健次 $*$. 大西 秀人*3 \\ 坂根 健*4. 安斉 敏雄 $* 5$
}

Microbiologically Influenced Corrosion of SUS304L and SUS316L Welds Caused by Aerobic and Anaerobic Bacteria in Groundwater (I)

- Laboratory Simulation Studies and Corrosion Behavior-

Yasushi KIKUCHI, Masayoshi Ozawa, Kenji ToHmoto, Hideto ONISHI,

Takeshi SAKANE and Toshio ANZAI

Synopsis : Microbiologically influenced corrosion was suspected in a corrosion failure of stainless steel (SUS316L) piping, carrying saline groundwater Laboratory simulation studies were planned to find out the mechanism of the corrosion. The groundwater from the same plant was transferred to the laboratory aseptically and used for the experiment. Both SUS316L and SUS304L welds (base metal, heat affected zone, weld metal) were exposed to the test solution. After $40 \mathrm{~d}$, corrosion sites were observed on the surface of coupons exposed to non-sterile groundwater supplemented with nutrients. In case of both sterile and non-sterile groundwater devoid of nutrient, the corrosion sits were not observed. Therefore, it is assumed that the corrosion occurrence requires bacteria, their activity and metabolism. The form of corrosion was pitting for base metal and heat affected zone, whereas, weld metal showed skeletal corrosion caused by preferential attack on $\gamma$-austenite.

Generally, the $\mathrm{pH}$ showed no change during exposure test. The potential increased during exposure to nutrient contained non-sterile groundwater for all coupons. In the case of both sterile and non-sterile groundwater devoid of nutrient, the potential did not show an increase for all the coupons. The potential increase that is influenced by bacteria is assumed to be the reason for the easy occurrence of corrosion.

Key words: MIC; SUS316L; bacteria; ground water; $\gamma$-austenite.

\section{1. 緒言}

微生物の関与する腐食（微生物誘起腐食, Microbiologically Influenced Corrosion, MIC) は一般の腐食と比べ, 材 料に比較的マイルドな環境において非常に大きな速度で進 行することが知られている ${ }^{1-4)}$ 。また, MIC は材料を選ば ず，チタン以外のほとんどの構造材料で確認されている。

MIC についてさまざまな検討がなされているが, 従来 の電気化学的な手法とともに微生物の挙動に注目した新し い手法を採り入れたアプローチが必要である。微生物の働 きについては鉄細菌，鉄酸化細菌，硫酸塩還元菌を対象 とした研究はなされているものの，報告が多いとは言えな (5-7)。しかし，環境中に生存する微生物は多種多様であ り，それぞれの微生物の共存状態やそれぞれの微生物の働 きを考慮に入れた検討が重要であると考えられる。
そこで著者らはSUS304鋼，銅および黄銅について，そ れぞれの腐食事例環境水中から微生物を採取し，それぞれ の微生物の挙動に注目して事例を検討, 報告してきた ${ }^{8-10)}$ 。 それらにより，一般的にMICの原因菌とされる独立栄養 細菌以外に, Staphylococcus sp.などの従属栄養細菌も MIC の原因菌になりうることがわかった。さらに，微生物の特 徴やその作用を明確にした上で MIC を議論することが重 要であることを提案してきた。

本研究も，臨海部の LNG 貯槽タンク付属配管部 (SUS316L 鋼) において漏水が発生した事例を基にして検 討を行った。すなわち, SUS316L鋼にとっては耐えられ る環境であったが，著しく大きな腐食速度をともなって漏 水したことから，MICの疑いがもたれた。本実験ではこの 事例地下水を入手し, 研究室レベルでの再現実験を実施す るとともに地下水中の構成微生物を特定し，好気性および

平成 14 年 2 月 14 日受付 平成 14 年 6 月 23 日受理 (Received on Feb. 14, 2002; Accepted on June 23, 2002)

* 大阪大学接合科学研究所 (Joining and Welding Research Institute, Osaka University)

* 2 大阪大学接合科学研究所 (現：(財) 発電設備技術検査協会) (Joining and Welding Research Institute, Osaka University, now Japan Power Engineering and Inspection Corp., 1370-1 Nishihara Tarasaki Hitachinaka 312-0003)

*3 大阪大学大学院生 (現：(株) 荏原製作所) (Graduate Student, Osaka University, now Ebara Corp.)

*4 武田薬品工業 (株) 開拓第 4 研究所 (Takeda Chemical Industries, Ltd.)

* 5 (株) 高田工業所 (Takada Corp.) 
嫌気性微生物の腐食に及ぼす役割について検討した。本報 はその第一報であり，この腐食事例環境より採取した水 (地下水) を用いた再現実験を行い，本事例が MIC か否か を検討した。さらに溶接部の表面状態が MIC 挙動に及ほ す影響を検討し，本事例水の MIC 挙動について述べ，第 二報では地下水中の構成微生物を特定し，好気性および嫌 気性微生物の腐食に及ぼす役割について述べる。

\section{2. 腐食事例}

この配管は地下水を地上へ汲み上げるもので，運転開始 から約 1 年経過後にそれらの溶接部で漏水が発生した。配 管内の流体は海水を含む地下水で, 温度は常温、1 月間 の間欠的な稼動であった。目視では局部腐食で $1 \sim 2 \mathrm{~mm}$ の 腐食孔が認められたが，腐食孔や金属組織などを観察した 結果, 溶接金属ではインクつぼ型のスケルトン状の腐食形 態を呈していた。微生物の付着は観察できなかったが，腐 食速度が著しく速いことなどの状況から考えて，微生物が 関与した可能性が高いものと判断した。

\section{3. 実験方法}

\section{$3 \cdot 1$ 事例水による再現実験}

\section{$3 \cdot 1 \cdot 1$ 供試液}

Table 1 に地下水の分析結果を示す。海水の混入のため $\mathrm{Cl}^{-}$イオン濃度が $12000 \mathrm{~g} / \mathrm{m}^{3}$ とやや高いが，SUS316L材に 対しては強い腐食環境ではないと考えられる。この地下水 とオートクレーブで $394 \mathrm{~K}-15 \mathrm{~min}$ の条件で滅菌した地下水 (以下, 滅菌地下水) を試料の浸漬用試験液とした。それ ぞれに栄養分 (Nutrient Broth (Difco), NB) を 0.01\% (0.1 g/ $1 l)$ 添加し, 栄養分の有無による腐食挙動の変化についても検 討を行った。

$3 \cdot 1 \cdot 2$ 供試材

Table 2 に示す組成の SUS316L および304L母材を用い た。母材についてはエメリー紙\#1000 およびダイヤモンド 研摩で $0.25 \mu \mathrm{m}$ まで研磨したものを供試材とし，表面状態 による腐食挙動の差を検討した。また，溶接は Table 4 に 示される条件での TIG 溶接によってビードオンプレート を行い, ビード幅が $10 \mathrm{~mm}$ 以上の溶接部を作製した。溶接 試料を Fig. 1 に示されるように切断し，溶接金属および熱 影響部 (熱影響部) の試験片を採取した。浸漬試料表面は エメリー紙\#1000 仕上げとした。なお，浸漬試料は銅線を ハンダ付けし, 浸漬面以外の部分を接着剤で被覆して実験 に供した。

\section{$3 \cdot 1 \cdot 3$ 浸漬実験}

滅菌済みの三角フラスコに供試液 $500 \mathrm{~m} l$ 採取し，供試液 中で各試料とも浸漬面が上を向くように静置して，293K で所定の時間保持した。浸漬時の試料の自然電位測定, 浸
Table 1. Chemical composition of groundwater $\left(\mathrm{g} / \mathrm{m}^{3}\right)$.

\begin{tabular}{c|c|c|c|c}
\hline $\mathrm{pH}$ & $\mathrm{Mg}^{2+}$ & $\mathrm{Cl}$ & $\mathrm{SO}_{4}{ }^{2}$ & $\mathrm{Na}^{+}$ \\
\hline 7.2 & 690 & 12000 & 3600 & 6540 \\
\hline \hline $\mathrm{K}^{+}$ & $\mathrm{Ca}^{2+}$ & $\mathrm{Mn}$ & $\mathrm{Fe}$ & $\mathrm{Cr}$ \\
\hline 55 & 3600 & $<37.5$ & $<0.03$ & $<0.05$ \\
\hline
\end{tabular}

Table 2. Chemical composition of coupons for exposure test (mass\%).

\begin{tabular}{l|c|c|c|c|c|c|c|c}
\hline & $\mathrm{C}$ & $\mathrm{Si}$ & $\mathrm{Mn}$ & $\mathrm{P}$ & $\mathrm{S}$ & $\mathrm{Cr}$ & $\mathrm{Ni}$ & $\mathrm{Mo}$ \\
\hline SUS304L & 0.006 & 0.46 & 1.17 & 0.032 & 0.002 & 18.55 & 10.34 & - \\
SUS316L & 0.007 & 0.58 & 0.79 & 0.030 & 0.003 & 17.49 & 12.32 & 2.15 \\
\hline
\end{tabular}

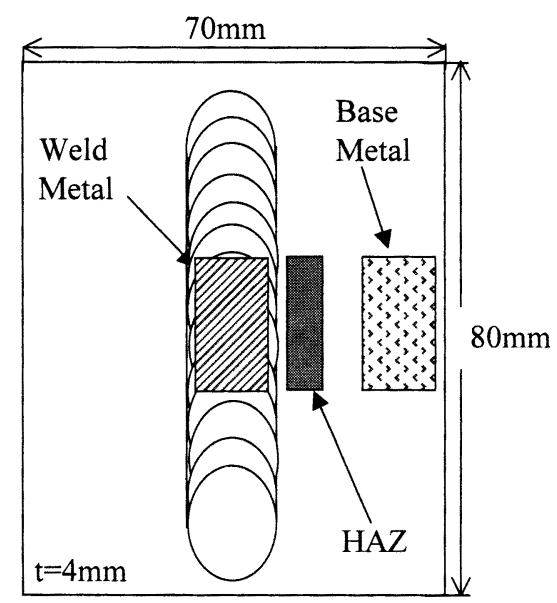

Fig. 1. Sampling of coupons.

漬溶液の $\mathrm{pH}$ 測定ならびに浸漬前後の表面を走査型電子顕 微鏡 $(\mathrm{SEM})$ により観察した。なお，自然電位の測定には 参照電極 $3.33 \mathrm{MKCl}-\mathrm{Ag} / \mathrm{Ag}$ 電極を用いた。

\section{4. 結果および考察}

\section{$4 \cdot 1$ 再現実験}

Fig. 2 に, 栄養分 $(\mathrm{NB})$ を含まない地下水および滅菌地 下水に 40 日間浸漬前後のSUS316L母材のSEMによる表面 観察結果を示す。滅菌地下水中では浸漬前後でほとんど変 化は観察されない。一方，地下水中への浸漬試料表面では， 微生物の付着および微生物の影響を受けたと考えられる黒 色部分が観察される。ここでは示さないが，この傾向は熱 影響部および溶接金属, さらにSUS304L鋼でも同様で あった。

Fig. 3 は栄養分 $0.01 \% \mathrm{NB}$ を含む地下水および滅菌地下 水に40日間浸漬した後のSUS316L母材のSEMによる表面 観察結果を示す。地下水に浸漬した場合，微生物の付着と 数 $\mu \mathrm{m}$ オーダーの腐食孔が多数観察されるが, 滅菌地下水 では確認されない。この傾向はSUS304L鋼でも同様で あった。

これらの結果より，本事例地下水は若干の栄養分を含む 場合, 微生物誘起腐食を発生することがわかる。しかし 


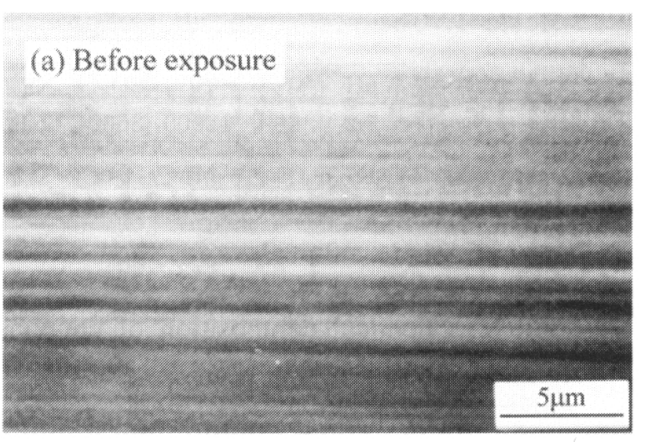

(c) Exposure in sterile groundwater.
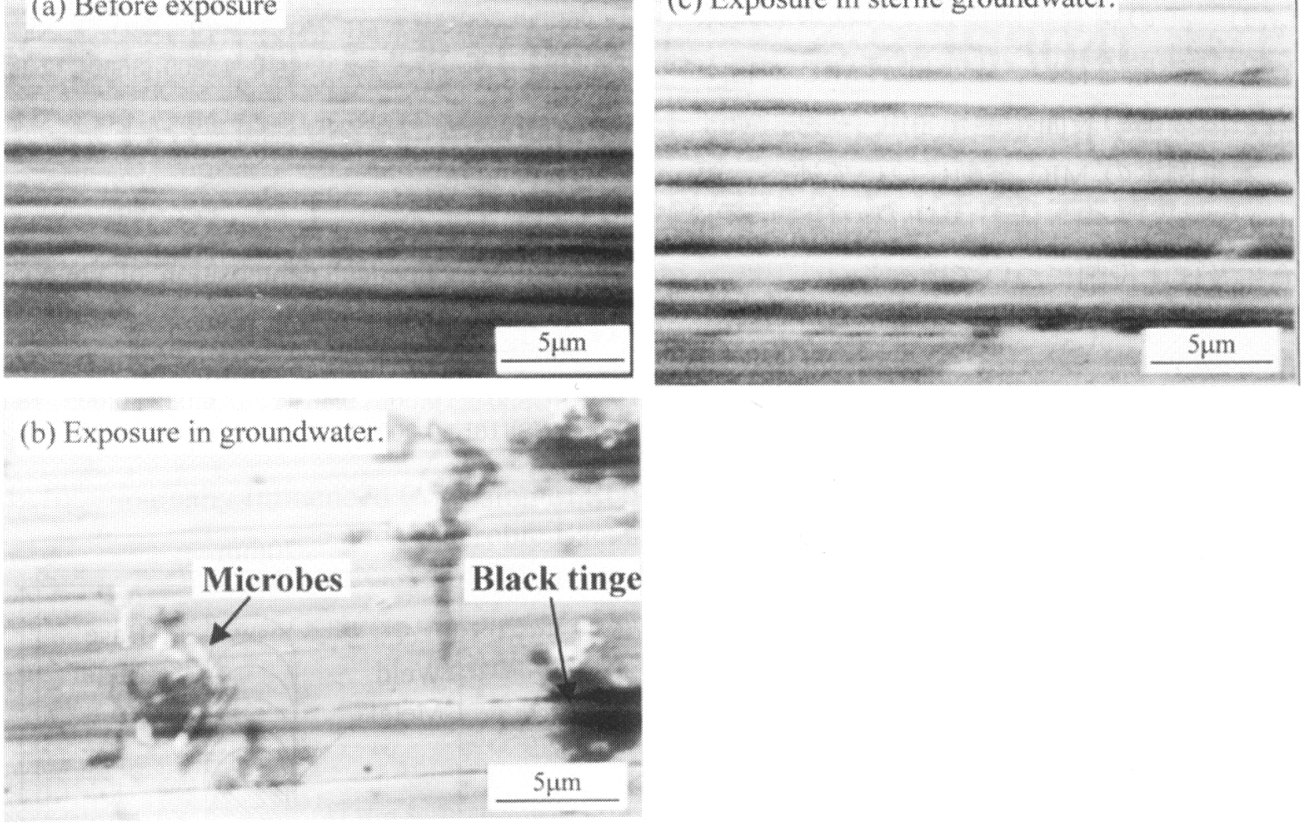

Fig. 2. SEM images of base metal surface after the $40 \mathrm{~d}$ exposure test (no-addition of Nutrient).

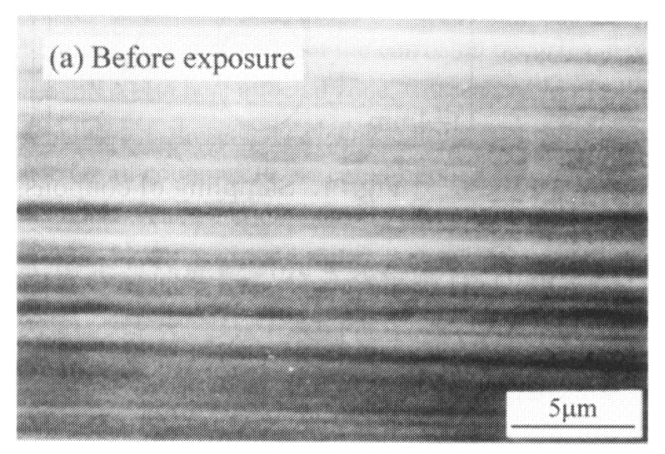

(c) Exposure in sterile groundwater.

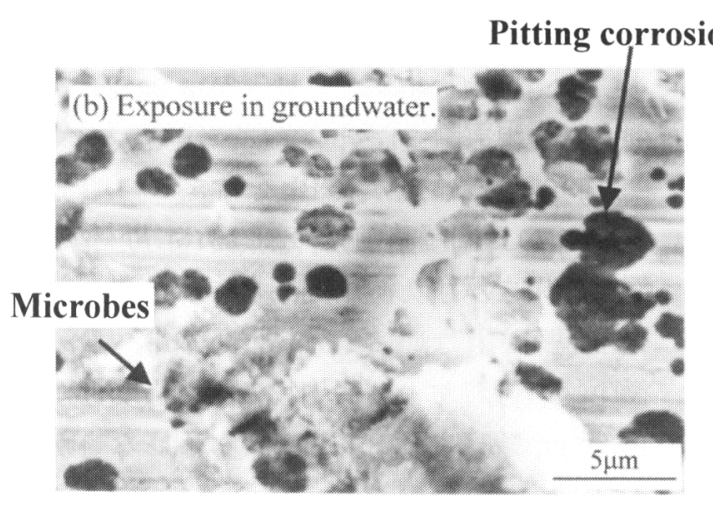

Fig. 3. SEM images of base metal surface after the $40 \mathrm{~d}$ exposure test (addition of $0.01 \% \mathrm{NB}$ ).

栄養分を含まない場合，微生物の存在下（地下水中）でも 40 日間の浸漬では腐食の発生に至らず，微生物の存在お よびその活性状態が腐食挙動に影響を及ぼすと考えられ る。一般に多くの配管設備中の流体は若干の有機物が存在 するとされて打り, それらの值も腐食環境モニタリングの

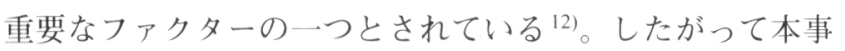
例地下水中にも微量な有機物が存在すると考えられ, その
ような栄養分の中で微生物がある程度の活性を得て腐食を 発生したと推察される。

ところで微生物誘起腐食は溶接部に多く発生しているこ とが報告されている ${ }^{1)}$ 。こで, 溶接金属の微生物誘起腐 食挙動を本事例地下水を用いて検討した。Fig. 4 に, 栄養 分 $0.01 \% \mathrm{NB}$ 含む地下水および滅菌地下水にSUS316L 溶 接金属を40日間浸漬した後の表面のSEM観察結果を示 


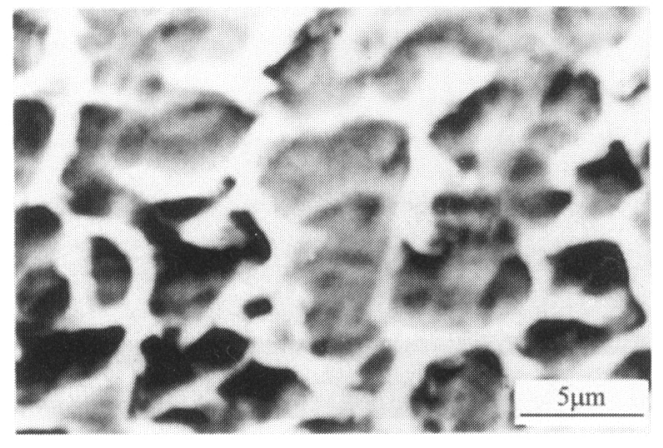

(a) Exposure in groundwater.

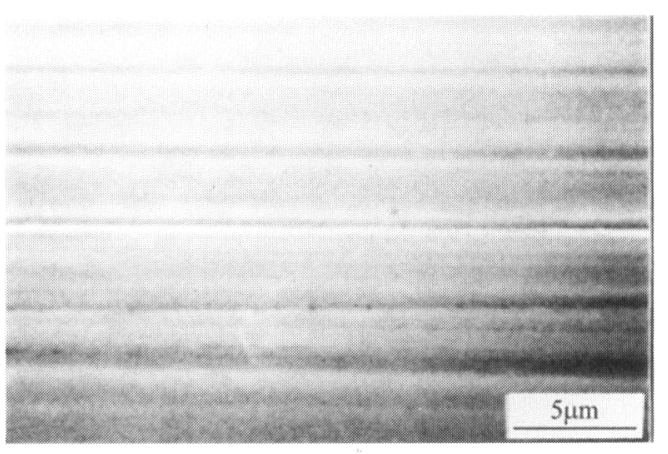

(b) Exposure in sterile groundwater.

Fig. 4. SEM images of weld metal surface after the $40 \mathrm{~d}$ exposure test (addition of $0.01 \% \mathrm{NB}$ ).

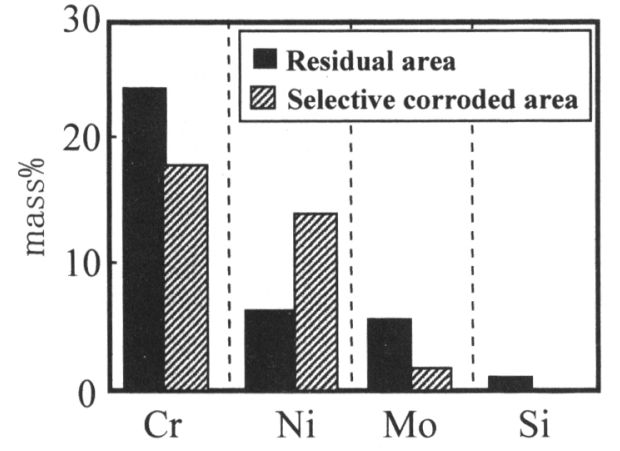

Fig. 5. EDX analysis of residual and selective corroded area for skeletal corrosion area of SUS316L weld metal after $40 \mathrm{~d}$ exposure test.

す。母材と同様に滅菌地下水中では腐食は発生していない が，地下水中では腐食が発生していることが観察される。 しかし，この腐食形態は母材とは異なり，選択腐食（スケ ルトン形状）形態を呈している。そこでEDX分析を行い, 選択溶解部, 残留部の組織を検討した。結果を Fig. 5 に示 す。ここで, EDX による半定量結果では残留部分の $\mathrm{Cr}$ 量 が約 24\% および Ni 量が約 6\%, 選択溶解部分の Cr 量が約 $17 \%$ および $\mathrm{Ni}$ 量が約 $14 \%$ となっており, 残留部分は $\delta$ Ferrite, 選択溶解部分が $\gamma$-Austeniteであると考えられる。 このスケルトン形状の選択腐食は微生物誘起腐食において しばしば報告されているが，事例によりそれぞれ異なった 組織が残留することが報告されている。

熱影響部は溶接金属部分と同様に微生物誘起腐食が発生 しやすい箇所である。そこで, 熱影響部の腐食挙動も観察 した。Fig. 6 に, 栄養分 $0.01 \%$ NB を含む地下水および滅 菌地下水に熱影響部を 40 日間浸漬した後の表面のSEM 観 察結果を示す。上記の結果と同様に滅菌地下水中では腐食 は発生していないが, 地下水中では微生物の付着および腐 食の発生が認められる。腐食形態および腐食の程度は母材 とほほ同様であり，とくに促進されていることはなかった。 この傾向はSUS304L鋼でも同様であった。

これまでの結果より，腐食の発生箇所に微生物の付着が 多く確認されている。このことからも微生物の付着が微生
物誘起腐食の重要な要因になっていると考えられる。微生 物の付着には, 表面の酸化皮膜や形状などの表面状態が影 響を与えると考えられる。そこで表面仕上げ状態を変化さ せ腐食挙動を観察した。Fig. 7 に，エメリー紙\#1000 打よ びダイヤモンド $0.25 \mu \mathrm{m}$ で表面仕上げしたSUS316L材を $0.01 \% \mathrm{NB}$ を含む地下水に浸漬した後の表面のSEM観察結 果を示す。15日間では微生物の付着は認められるが, 腐 食は生じていない。さらに, 浸漬が 40 日間に及ぶと双方 とも腐食孔が多数確認された。しかし, 表面状態による微 生物の付着および腐食挙動には差異は認められない。ここ での実験は静置状態での実験であり，溶液の流れはほとん どない。そのため, 微生物の付着挙動に表面粗度の差が認 められにくかったと考えられる。

地下水および滅菌地下水に浸漬時の溶液の $\mathrm{pH}$ ならびに SUS316L母材の自然電位変化を Fig. 8 に示す。pH の変化 はさほど顕著ではないが, 自然電位測定では上記 SEM 観 察により腐食が確認された $0.01 \%$ NB を含む地下水中で のみ電位の貴化が認められる。とくに浸漬 15 日間では $-200 \mathrm{mV}$ (vs. $3.33 \mathrm{MKCl}-\mathrm{Ag} / \mathrm{Ag}$ ) であるが, 40 日間では 50 $\mathrm{mV}$ を超えている。一方, Fig. 7 に示されたように, 浸漬 15 日間では腐食は生じないが, 40 日間では腐食が生じて いることが観察されている。このことは, 15 日間の浸漬 より 40 日間浸漬したときの方がより隙間腐食を誘起され やすい環境に変化したことを示し, 本腐食挙動が単純に浸 漬時間に依存したものではないことを示唆していると考え られる。このような貴化現象は多くの研究者によって確認 されており，その発現についてはさまざまな機構が提案さ れている ${ }^{13-15)}$ が，ここでの電位貴化に及ぼす微生物の作 用は今のところ不明である。なお, これらの傾向は, 溶接 金属，熱影響部およびSUS304L鋼でほぼ同様であった。

\section{5. 結論}

海水を含む地下水によるSUS316L鋼の腐食事例を微生 物誘起腐食の観点から, 研究室における母材および溶接部 


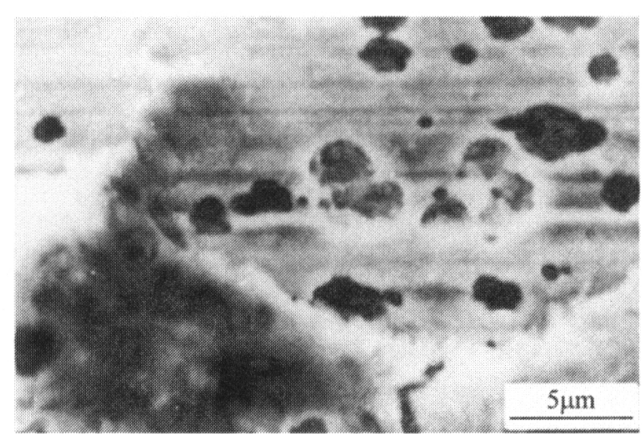

(a) Exposure in groundwater.

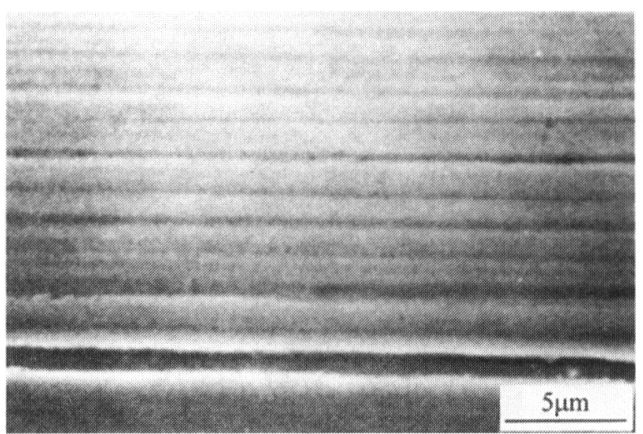

(b) Exposure in sterile groundwater.

Fig. 6. SEM images of HAZ surface after the $40 \mathrm{~d}$ exposure test (addition of $0.01 \% \mathrm{NB}$ ).

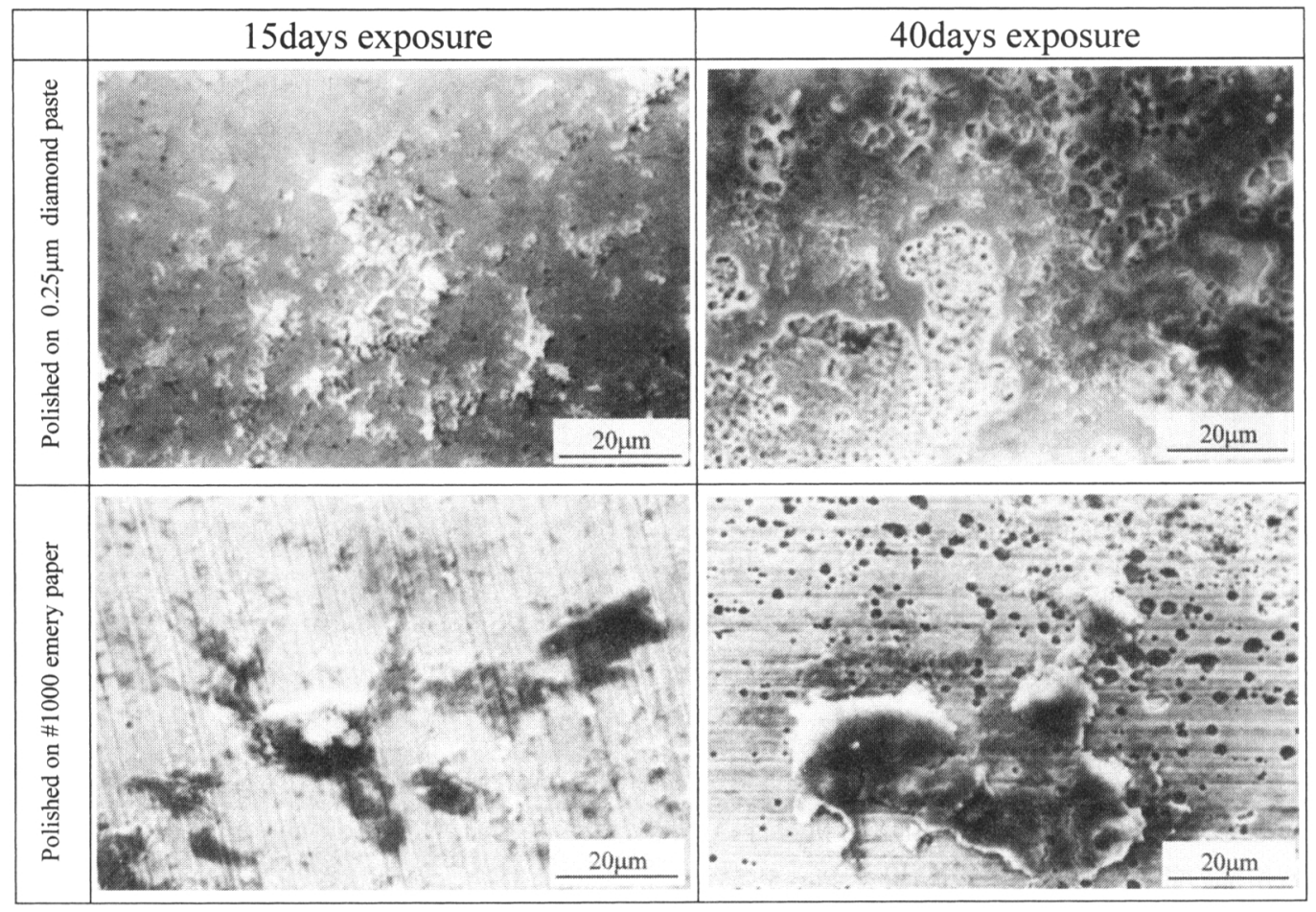

Fig. 7. Comparison of corrosion behavior in SEM images under the influence of finish polishing for SUS316L base metal surfaces.

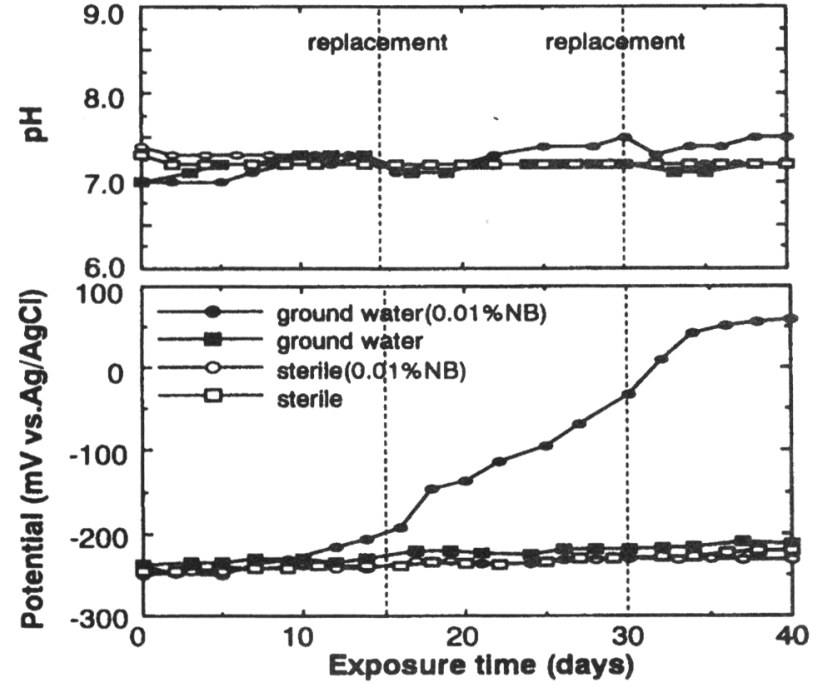

Fig. 8. Variation of $\mathrm{pH}$ and corrosion potential in sterilized and non-sterilized ground water on SUS316L base metal as a function of exposure time.
の浸漬実験によって検討し，以下の結果を得た。

(1) 地下水に微量の栄養分 $(0.01 \% \mathrm{NB})$ を含む溶液で浸 漬実験を行った結果，各試料に腐食が発生した。滅菌した 地下水では腐食が発生しなかったことから, 本事例への微 生物の関与が明らかとなった。

（2）栄養分を添加せず地下水をそのまま用いて浸漬実 験を行った場合には，腐食が発生しなかった。このことよ り，腐食に対し微生物の活性度および代謝活動が大きく影 響することが示唆された。

（3）溶接部において $\gamma$-Austenite が選択的に腐食され, スケルトン状の腐食形態が観察された。一方，熱影響部は 母材と同様の腐食傾向を示した。

(4) $0.01 \% \mathrm{NB}$ を含む地下水中への浸漬試料において 自然電位の貴化が確認された。なお, 滅菌地下水および NBを含まない地下水中では貴化は認められず, この貴化 
現象への微生物とその代謝活動の寄与が示唆された。

\section{文献}

$1)$ Y.Kikuchi: Bull. Jpn. Inst. Met., 32 (1993), 393.

2) H.M.Herro: Corrosion/98, NACE International, Houston, (1998), Paper No. 278.

3) A.Haugenauer, R.Hilpert and T.Hack: Werkst. Korros., 45 (1994), 355.

4 ) S.W.Borenstein: Microbiologically Influenced Corrosion Hand Book, Woodhead Publishing Ltd., Cambridge, (1994), 161.

5) G.J.Licina: Sourcebook for Microbiologically Influenced Corrosion in Nuclear Power Plants, Electric Power Research Institute, Palo Alto, (1998).

6 ) K.Endo, K.Matsuda and H.Ohno: Zairyo-to-Kankyo, 42 (1993), 734.
7 ) Y.Yao, K.Masamura, T.Kondou and Y.Ujiie: The 125th JSCE Symposium, JSCE, Tokyo, (1999), 102.

8 ) F.Kajiyama: The 100th JSCE Symposium, JSCE, Tokyo, (1994), 55.

9 ) Y.Kikuchi, K.Tomoto, T.Okayama, F.Matsuda, M.Nishimura, T.Sakane and Y. Kaneko: J. Jpn. Inst. Met., 61 (1997), 486.

10) Y.Kikuchi, K.Tomoto, T.Kanamaru and T.Sakane: Zairyo-to-Kankyo, 47 (1998), 468.

11) Y.Kikuchi, M.Ozawa, K.Tomoto, T.Kanamaru and T.Sakane: J. Jpn Copper Brass Res. Assoc., 38 (1999), 157.

12) H.Takahashi, H.Saito, T.Tezuka, S.Mizushima and H.Yamaguchi: Biseibutsugaku-Nyumonhen, Baihuukan, Tokyo, (1991).

13) R.J.B. Scott: Mater. Perform., 39 (2000), 54.

14) M.Akashi: The 125th JSCE Symposium, JSCE, Tokyo, (1999), 55.

15) T.Amaya and H.Miyuki: Zairyo-to-Kankyo, 44 (1995), 94. 